DOI: $10.22616 /$ REEP.2020.030

\title{
Tales of Emotions: A Work in Progress of a Tool for Teaching Emotional Intelligence
}

\author{
Lolita Jolanta Navickienė PhD \\ Lithuanian Academy of Music and Theatre, Vilnius, Lithuania \\ lolita.jolanta.navickiene@gmail.com
}

\begin{abstract}
Although the benefit of developing a child's emotional intelligence for the child's personality education has been beyond any doubts, methodological literature that focuses on 1 - 3-year-old children is still scarce in Lithuania. The aim of this article is to present the experience accumulated while creating a new programme for emotional intelligence development, entitled "Tales of Emotions", based on author's Method of Emotional Imitation. Particularly, it discusses the competences necessary for the developer and the teacher as well as challenges and problems encountered in the process of programme development and its implementation. The main methodological approach used in this text is self-observation or "diary" method that led to emphasize the non-linear character and the complexity of the process of method development. Importantly, the findings of this article provide the guidelines for creating a framework to develop the emotional intelligence of 1-6-year-old children and their parents while currently the emotional literacy of 1-3-year-old children is traditionally considered to be a family prerogative.
\end{abstract}

Keywords: emotional intelligence, method of emotional imitation, emotional literacy, preschool education.

\section{Introduction}

The research conducted worldwide (Goleman, 2005; Bradberry, Greaves, 2009; Clark, 2018) prove that in most cases emotional intelligence (EI) predetermines the individual's success and that development of logical thinking and intellectual potential only is not necessarily a prerequisite for successful life. The previously conducted research studies also reveal that emotionally literate people become more responsible, careful and happier adults in the future. They also have better careers, are able to cope with life challenges and feel happier. However, development of emotions in early childhood and pre-primary education receives too little attention as if forgetting that an individual not only thinks but also has feelings (Slušnienè, Balčètienė, 2016). In an attempt to fill this gap, the author of this paper has participated in an initiative to develop a programme focusing on emotional literacy of 1-6-year-old children in Lithuania.

Similarly, to other post-soviet countries Lithuanian schools face multiple problems often leading to bullying among children. Indeed, children's destructive behaviour, negative emotions and feelings obstruct development of relations, whereas positive emotions, pleasant communication, collaboration, appreciation, sharing, respect and tolerance can contribute to personal improvement and influence the quality of activities. The previous research also shows that the main attention in schools is allocated to development of mental intelligence (thinking, understanding, imagination, creativity) and other abilities. All this evidences that EI and categories of emotional potential are underdeveloped or have not reached the necessary and desirable level in educational science (especially in Lithuania) (Slušnienè, Balčètienè, 2016). Scant attention to development of emotions leaves the aspects of emotion quality (surprise, joy, disgust, resentment, anxiety, sadness), dynamics (duration, intensity) and external expression (language, gestures, mimic) aside.

In the first and second decades of the $21^{\text {st }}$ century a number of research papers have been published, which target at emotional intelligence and possibilities for its development (Goleman, 2005; Goleman, Boyatzis, McKee, 2013; Bradberry, Greaves, 2009; Clark, 2018). The programmes for EI development, such as "Zippy's Friends", "Let's Overcome This Together", "Second Step", "Kimochi", "Crossroads of Teens", "Keys to Success", "Life Skills Education", "SEAL", "Apple's Friends" and others, have also became available. It focuses on helping the teachers to enable children to recognize and understand the basic emotions. For example, "Zippy's Friends" aims to give children better skills in communication, conflict resolution, self-assertion, co-operation, self-control and empathy (Clarke, 2011). This is in line with previous research that has found that programmes focusing on a single phenomenon have proved less effective than those that integrate training of various competencies (Weissberg, Elias, 1993).

H.J. Ahn (2005) suggests that children acquire their emotional knowledge from adults so the teacher should 
encourage the children to verbalize their emotions or seek other constructive ways of expressing it. The importance of such a strategy comes from the attitude that once the emotion has been named it can be controlled and immediately starts to decline in intensity (Briers, 2008). However, teachers in many countries face difficulties in acquiring such skills as socio-emotional education is mostly attributed to the family sphere (Rosenthal, Gatt, 2010). According to D.W. Winnicott (1992), A. Bagdi and J. Vacca (2005), the period of early childhood sets the stage for how well children view themselves, each other, and their world. At this stage children already perceive the importance of people-to-people communication. They express it through the need to have friends, are able to enlist the qualities characteristic of a good friend or to help or support a friend. Obviously, EI has to be developed as early as babyhood. However, parents lack necessary experience. Even more, to express and understand own emotions are a challenge to many adults. This particularly concerns positive emotions as their display may presuppose vulnerability. Based on the experience of the author of this paper (see Methodology), clear expression of positive emotions is impeded by an insufficient number of drama societies at school, underdeveloped ability of school students to control facial muscles, to understand the body language of surrounding people, by tension, stress or other situations, where demonstration of positive emotions is problematic in general. Therefore, this article presents the encountered challenges and experience acquired while working on the development of programme for 1-6-year-old children's EI, which is grounded on the Method of Emotional Imitation (MEI).

Method of Emotional Imitation is a method of promoting school learners' musicality and musical abilities as well as their self-education imitating the content of emotional intonations of music compositions or experiences lived through by an imaginary character, when this content is evoked integrating other kinds of art (Navickienè et al., 2019). Thus, the method that facilitates expression of emotions through imitation and mimicking in various kinds of art may significantly contribute to developing emotional literacy. The trust in using such a possibility for creation was predetermined by the long-established experience in applying MEI in prenatal, early, non-formal and formal music education in Lithuania. The distinctive feature of MEI is that all the educational goals (cognitive, psychomotor, training, emotional and moral) are implemented in the process of such education (Navickienè, 2016). In terms of application, the method is universal and can be integrated into other kinds of art in an easy way. With the help of MEI, performing music aims at development of the individual's expressiveness, susceptibility, creativity and musicality through musical activities. That is why, this method perfectly complies with the goals of the programme for emotional literacy.

\section{Peculiarities of developing methodological programmes}

As it is provided for in "The Methodological Recommendations for Development of Early Childhood Education" put forward by the Ministry of Education and Science of Republic of Lithuania, the changes in the country's economic, social and cultural life resulted in by globalisation, sustainable development, information society development, transformations in values and value-based attitudes, obliges members of education community to carefully comply goals of education with the needs of children, families, community and the state (Skripkiene, 2005). However, namely the teachers, who develop early childhood education programmes for their institutions are able to address the needs of community, parents' expectations, to choose the desired content and methods best and, thus, to provide education with an opportunity to become more varied and enriched as well as to better meet different educational needs of children (Skripkienè, 2005). Therefore, while preparing for the programme development, it is particularly important to allocate attention to the analysis of philosophical, psychological and pedagogical aspects in accordance with strategical documents that provide for a contemporary approach to a child and his/her education as well as to revelation of the attitude towards the child and childhood and to links of child's needs and education. This necessitated a review of the previously designed programmes.

In the $21^{\text {st }}$ century various programmes for enhancement of social and emotional competences have been introduced in educational institutions of our country but the process of their introduction and implementation has not been consistent. The programmes have been used only by some teachers and the main focus has been allocated to academic results. After the analysis of the most popular programmes ("Zippy's Friends", “Apple's Friends", "Kimochi"), several commonly shared aspects were identified: children play with toys that reflect emotions and feelings, toys make some situations visible and audible, which makes expression of certain emotions possible. A considerable attention is laid on recognition and acceptance of both negative and positive emotions and feelings, on learning to 
make friends, establishment of relations. This is attractive to kindergarten-age children but the question how to speak about emotion to one-year old children and their parents still remains open.

\section{Requirements for a teacher in early childhood education}

Before the start of programme development, it was important to understand the requirements for this activity. The work of D. Bagdanavičiene shows that teacher's competency is a result of changing world and dynamic transformations in new knowledge, which is predetermined not by obtained qualifications but rather by an ability to adapt to changes, when the personal competence and ability to constantly improve it plays a significant role. The transformations in the pedagogical system, didactic processes, teaching/learning goals, teacher-student relation are based on a new bottom-up principle of planning teaching instead of the old top-down one. The above-mentioned comprise challenges posed on a contemporary teacher, which exceed traditional boundaries of teacher's competences (Bagdanavičiené, 2016). Thus, competences of teachers, who work in school of modern society, expand significantly and, according to R. Čiužas (2013), result in a big number of roles - the teacher becomes a conveyer of information, a subject teacher and organiser, a social pedagogue, an experienced senior friend, a philosopher, an innovator, a researcher, a promoter of learning processes, a collaborating colleague, a consultant, a mediator of changes and a methodologist. The requirements imposed on an early childhood teacher are even higher. The teacher has to be a personality prepared to communicate with children employing a sense of trust, love, warmth and respect. In other words, a teacher has to be an "ideological figure", who educates and develops more humane and cultured personalities that strive for social ideals, perceive the phenomenon of childhood and performs the role of a child's caregiver, a creator of opportunities, an intermediate of education and an establisher of partnership with the family, because an early childhood teacher builds up what is most important for the society, i.e., the individual's internal and external world during one of the most complicated period in his/her life - the childhood. B. Tracy also emphasises the same idea pointing out that "the greater clarity you have regarding your values on the inside, the more precise and effective will be your actions on the outside" (Tracy, 2010, 48).

The aim of this article is to present the experience accumulated while creating a new programme for emotional intelligence development, entitled "Tales of Emotions", based on author's Method of Emotional Imitation.

\section{Methodology}

The tasks of the study are:

- to review the current trends and specific aspects of emotional intelligence education;

- to introduce the Method of Emotional Imitation in the context of emotional literacy;

- to describe the process of designing the programme "Tales of Emotions" for EI education;

- to provide the guidelines for creating a framework of methodological programmes aimed for developing the emotional intelligence of 1 to 6 -year-old children and their parents.

Seeking to record and share all the acquired experiences, the social research method of self-observation or "diary" method was employed (Bolger, Davis, Rafaeli, 2003; Engin, 2011).

The development of "Tales of Emotions" had several methodological inputs. Firstly, the EI theory developed by J.D. Mayer and P. Salovey (Mayer, Salovey, 1997) was taken into account, which was used to determine five skills influencing the EI: recognizing emotions in oneself and others, understanding the causes and consequences of emotions, precisely naming emotions, expressing emotions in a context relevant way, and regulating emotions (Brackett, Rivers, 2014). The set of these skills was termed RULER and was proposed as a baseline for developing EI (Hagelskamp et al., 2013). Moreover, the authors of this set suggest the usage of "the mood meter", suitable for children as young as 3 years old and enabling them and their parents to understand their emotions (Nathanson et al., 2016). The concept of social and emotional learning (SEL), emphasizing that social and emotional skills are essential not only for the general wellbeing of a person and their sustainable relations with others but also for the academic success, was a second major influence while developing "Tales of Emotions" (Durlak et al., 2015; Heckman, Kautz, 2012; Levin, 2012). The importance of SEL could be illustrated by a calculation stating that parents' investment in their children's EI will result in an 11-fold higher 
added value (Heckman, Masterov, 2007; Belfield et al., 2015). This information prompted the thorough inclusion of moral themes and social context in the programme.

The professional experience of the author of this article was instrumental in developing the Method of Emotional Imitation, and subsequently proposing its extensive application in "Tales of Emotions". The author has worked as a music teacher in secondary education (Trakai Vytautas Magnus Gymnasium, 1988-2008; Trakai Art School, 2002-2006), as a professor in music education (Lithuanian Academy of Music and Theatre, 1992-2002, then 2012 to present), and as a tutor of prenatal and early music education (Musical Educational Health Promotion School "Sveikutis", 2003 to present). This experience showed that the MEI functions in multiple educational contexts (Navickienè, 2016; Navickienè et al., 2019) and suggested its potential in teaching emotional literacy. Experiencing the emotional state of a piece of music or art, describing and imitating it - at the very core of the MEI - were seen as a key for children and their parents to access their own emotions, facial expressions, and body language. Moreover, focusing on details of recognizing, describing and expressing emotions through singing, rhythmic exercises or music listening activities perfectly fits the five skills of the RULER set. As the author of the programme was also the person to implement it for the first time during the process of its development, it was essential to capture in details this experience. The author of this paper together with the initiator of the programme R. Lazdin, and the children psychologist V. Grigorjeva took notes on each lesson and the general process of the programme. All lessons were filmed and then discussed, along the notes, in a weekly meeting following the lesson. Throughout the process, the communication between the author, the initiation and the assisting psychologist continued (several times a week, sometimes daily) online. As discussed further, this approach proved instrumental in capturing the non-linear nature of method development.

\section{Results and Discussions}

\section{The process of developing the programme "Tales of Emotions"}

The beginning. The programme was started in June 2019 and there are plans to finish it in February 2020 (during the preparation of this text the programme was still in progress). Initially, the process of creation was more of piloting character, and continuous consultations with the initiator of this programme, R. Lazdin, were held. Working in the field of early education since 2013 and having accumulated extensive experience through designing the programme "Seven Intelligences", R. Lazdin was more experienced in designing programmes for infants and young children (Lazdin, 2018). The duration and volume of the programme for emotional intelligence was clearly defined from the beginning - 16 lessons (one lesson per week). The specific developmental period was also chosen, i.e. 1 to 6-year-old children. It was decided to divide children into two groups: 1 to 3 -year-old children comprised the first group and the second one consisted of children aged 3 to 6 years old. The initial plan was to create "Tales of Emotions" within the period of several months but the very beginning of creation was tiring and more complicated than planned because there was a feeling that at first the author of the programme lacked special psychological knowledge and a model programme. This is in line with the findings of M.K. Rosenthal and L. Gatt (2010), suggesting that teachers in different countries are thought to focus on children's linguistic and cognitive skills while leaving the socio-emotional development to the family sphere. Such an understanding resulted in engagement of a professional psychologist into the process of programme development. After the analysis of the popular programmes for EI education ("Zippy's Friends", "Kimochi" and "Apple's Friends") it became clear that using them as model programmes, the final results would not be satisfactory as the element of novelty of "Tales of Emotions" would not be distinct and the programme would be based on well-known facial expressions learning cards, games with toys and situation-based tasks. Therefore, it was decided to use the Method of Emotional Imitation and to consider it an exceptional characteristic of "Tales of Emotions".

Choice of topics for "Tales of Emotions". Perceiving the importance of this stage, considerable time was allocated to it. In the beginning it was decided to create "tales" taking into account the importance of moral topics, e.g., "Types of Love", "Importance of Hope", "Importance of Patience", "Love for Nature" and others, and their logic sequence because all the tales had to be interrelated by their scenarios, which had to be used for the plot line of journey to the world of emotions and feelings. From the very beginning it was suggested including a character, i.e. a specially made puppet Prince (Princas), into all the tales but the consulting psychologist emphasised that Prince would be better understood by elder children, whereas the 
younger ones need a character from animate nature. For this reason, the hand puppet Little Bunny (Kiškutis) was introduced. Moreover, the audio character Knowledge Fairy (Žiniu fëja) dubbed by the initiator of the programme was created to enhance children's imagination.

Before choosing the topics of the programme the scenario of "Tales of Emotions" was written: Prince William-Nilliam (Princas Noriukas-Nenoriukas) (the prototype of the character is the main character of "The Little Prince" by Antoine de Saint-Exupery) is under a spell and he does not know his own name and that of his kingdom. Knowledge Fairy, Teacher, Little Bunny, mothers and children help him during his journey to the kingdom reigned by Three Kings, where he will find out the real names and then everybody will be happy again. Every lesson of "Tales of Emotions" was assigned moral ideals and the most relevant emotions were associated with them. However, such an objective appeared to be insufficient because it was important to link moral topics and emotions to be developed with knowledge of music. This new challenge encouraged creation of a certain "matrix", when every topic of the tale to be analysed was linked with music knowledge, emotion imitation and creative tasks, home games allocating considerable attention to expression of positive emotions. For example, the topic "Expression of Positive Emotions" is divided into the following sub-topics: "Ability to Express Liking"; "Ability to Express Love, Tenderness"; "Meaning of Hug"; "Importance of Hug"; "Meaning of Voice Timber", "Song (Solo and Choir)"; "Music Notes"; "Ta (Quarter Note) and Ti Ti (Eight Note)". The importance of homework was constantly emphasised by the contracting party of the programme; therefore, it was decided to create special "home games for the whole family". The intention was to give children a generously illustrated file with the main topics of the lesson, pictures depicting events and versed quatrains conveying the most significant moments in the lesson plot. In this way by the end of the programme parents will have collected a set of sixteen home games and a tale in thirty-two verses, which will help children to revise and remember the learnt programme.

Choice of emotions. The choice of the main emotions for the programme became a serious challenge, when it turned out that there was no one number of them. For a long time, it was thought that six types of basic human emotions can be distinguished: anger, disgust, fear, happiness, sadness and surprise and all the other emotions are only combinations of the basic ones. According to P. Ekman (2007), there are five main and universal emotions: anger, fear, sadness, happiness and disgust. The research presented by A.S. Cowen and D. Keltner disclosed more distinct (but interrelated) emotions that can be experienced by an individual. The research conclusions provided for 27 distinct emotions, which include fear, awkwardness, calmness, confusion, disgust, nostalgia, sadness, sympathy, horror and triumph (Cowen, Keltner, 2017). R. Plutchik (2000) pointed out eight basic emotions (joy, trust, fear, surprise sadness, disgust, anger, anticipation) with three levels each. Taking into consideration the age of participants in the programme "Tales of Emotions", ten most relevant emotions to children were chosen: disgust, sympathy, anger, surprise, joy, sadness, fear, trust, calmness and anticipation. It was decided to turn these emotions into Emotion Fairies (Emociju fejjos), which became significant characters of the whole programme and to visualise them drawing their expressive portraits and body language complying with the emotion.

The strategy of writing the text of "Tales of Emotions. The "polishing up" of the strategy for creating the text of tales was necessitated by the fact that in the process of programme development, the author had to give lessons to two groups of children. The process of making final decisions about the strategy for texts of "tales" lasted for a long time, i.e. almost two months. This strategy had to be clear and convenient for lessons. In the beginning structured dialogues were created for every tale but this strategy was given up after the first lessons because it was complicated to learn long texts by heart and the author improvised more on the basis of dialogues during the lessons. The final decision was made to write very concise texts of general character containing the main actions in the content of a lesson. However, later the practice showed that it was worth preparing a short separate gist on the bases of these general theses, which would help the teacher to effectively remember the plot of the tale. The succinctness of the gist turned out to be of utmost importance, which led to shortening the text of one tale, which was necessary for a detailed narration of the idea and plot of the tale from around ten pages to one. Thus, next to a detailed text of each tale a gist was prepared as well.

Method of Emotional Imitation and interdisciplinarity. Since 2003, the author of the article delivered an original programme of early musical educational health promotion for 3 - 12-month and 13 - 36-monthold children. After starting the work on "Tales of Emotions" it soon became clear that emotional intelligence in this programme will be developed in a more convenient way if other kinds of art, and especially music, 
are employed. Then the problem of repertory arose because the topic of each tale required songs, specific knowledge, dances and expression of positive emotions had to prevail in all their texts. The author of the article generalised her experience obtained in early music education in two methodological publications: "Songs of Mothers-to-Be" (Būsimųjų mamų dainos) (Navickienè, Navickas, 2005) and "The Family Book" (Šeimos knyga) (Piličiauskaite, Navickas, Piličiauskas, 2017). Some musical activities (songs, games) from "The Family Book" turned out to be suitable for the plots of "Tales of Emotions" and were included into the list of suggested songs but the other had to be specially written. For this it was decided to cooperate with the composer A. Navickas, who had contributed to creation of the above-mentioned publications.

The problems of content in "Tales of Emotions". Making attempts to supplement the content of each tale with various activities, a dilemma aroused to decide upon which of the goals of the programme had to be prioritised: emotional education or attractiveness and visual effect of the programme. In the beginning the main focus was on expression of emotions but very soon this task appeared to be too challenging for children and for parents because it is not easy to express positive emotions. Moreover, children of the younger group (1-2-year olds) are more agile and they retain their attention for a relatively short time - just several minutes. The decision was made to allocate significant attention to organisation of various attractive activities for children without overshadowing the main goal, i.e. emotional literacy. On the basis of her experience accumulated while creating the programme "Seven Intelligences", the initiator of the programme advised to employ a lot of various properties, what is attractive to children and makes the very process of education more entertaining. Every lesson had to include texts of the used vocal repertory, aids for games in accordance with the developmental periods, audio records of music and the voice of Knowledge Fairy. This proved to be successful but not enough as four lessons showed that singing, dancing and playing music were the most favourable activities among children. It was decided to make the music part of the programme more intensive including playing small percussion instruments, Bongo drums, Carl Orff's xylophones and glockenspiels. Children and parents were invited to learn, live through and convey various emotions while playing the above-mentioned instruments.

The requirements for the programme developer. In the beginning of work on "Tales of Emotions" the author had intentions to mainly focus on the writing scenarios for each lesson. However, it later became clear that the very creative process would be of non-linear character, i.e. there would be a constant search for the best strategy for programme structure, which would undergo evaluation in the process of creation and the programme would be rewritten and criticized. There was an exceptional opportunity to test the programme in the process of its development (after a few tales were written, they were presented in the summer camp organised by the programme initiator, one of the tales was staged, some lessons were delivered, the constant feedback process was going on among members of programme developers (the initiator, the developer, the psychologist, the property master and parents involved in the programme)). Later, the main attention was allocated to adaptation of the lesson scenarios to the groups of 1-2-year-old and to 3-6-year-old children, incorporating a constant feedback from the parents and observing the reactions of the children; this significantly facilitated the creative process. Thus, along the necessary knowledge of peculiarities of the chosen developmental period (1-6 years old) and psychology, the necessary good musical abilities to sing, play and improvise, the author had to create music, to write verses, to design tasks that comply with the developmental period of children and to write artistic scenes and texts and, what turned out to be most challenging, to create mise-en-scenes that can be really implemented by a teacher working alone, with puppets and different audio records. All this required not only pedagogical, musical but also stage and artistic experience, i.e. to be able to control facial muscles, to be expressive, to change voice timbre and to be able to work puppets. It was decided to make the latter challenge easier, i.e. not to use the puppet Prince during the whole lesson and to "inhabit" Little Bunny in the pocket of an apron, which is specially made for the Teacher to enable her/him to more freely perform various activities and complete tasks.

\section{Conclusions}

Generalising the experience gained developing the programme "Tales of Emotions" targeted at emotional intelligence, it can be stated that:

- a short overview of the current trends and specific aspects of emotional literacy development revealed that the majority of programmes for EI education focus on early childhood and 
pre--primary children. They are taught to be friends, to establish harmonious relations, to recognise and accept negative and positive emotions. However, development of 1-3-year-old children's EI is seen as the family's prerogative;

- a contemporary early childhood teacher in modern society has to perform a wide range of roles closely related to the process of education, nurturance of spiritual values, their analysis, creation, collaboration with learners, their parents and colleagues; it is therefore essential to practically implement the requirements of the teacher as an "ideological figure";

- in the context of the programme for emotional intelligence education, MEI is a way and aid for learning emotions and, having learned it, to express and develop the self, to be able to feel others and to learn to apply the obtained knowledge in own daily life;

- musical activities and imitation of emotions - the core elements of the MEI - present an advantage over other existing EI approaches in its attractiveness and accessibility to 1-6-year-old children;

- moral value education is inseparable from emotional intelligence; therefore, various moral topics help to speak about emotions and to understand the meaning of their display;

- development of the programme for emotional intelligence is the process that requires creative potential, psychological knowledge, pedagogical experience, musicality and artistic abilities as well as poses numerous challenges;

- the storyline of "Tales of Emotions" participated in shaping the methodological aspects of the programme development, witnessing the mutual impact between the creative and implementation phases of the method development;

- the process of creating "Tales of Emotions" has been non-linear, i.e. it requires constant observation, compliance of theory and practical implementation, prudent evaluation and optimisation;

- in the process of programme creation, it is necessary to ensure the distribution of tasks and expert assistance, when an experienced specialist assumes responsibility for a relevant area (in this particular case an educational researcher, a music teacher, a psychologist, a manager, a composer and a property master);

- "work in progress" type approach to method development is a singular opportunity to design and test a programme aimed at specific target audience (in the case of "Tales of Emotions" - 1-6-yearold children and their parents), challenged by a real-time feedback from programme participants.

\section{Bibliography}

1. Ahn H.J. (2005). Child care teachers' beliefs and practices regarding socialization of emotion in young children. Journal of Early Childhood Teacher Education, 26(3), 283-295. doi: 10.1080/10901020500371155

2. Bagdanavičienè D. (2016). Pedagogo profesijos kompetenciju vertinimas priešmokyklinio ir ikimokyklinio ugdymo mokykloje [Assessment of Teacher's Professional Competences at Pre-primary and Early Childhood Education Institutions]. (Master's Thesis, Lietuvos edukologijos universitetas, Vilnius). Retrieved from https://gs.elaba.lt/object/elaba:15930923/15930923.pdf (in Lithuanian)

3. Bagdi A., Vacca J. (2005). Supporting early childhood social-emotional well-being: The building blocks for early learning and school success. Early Childhood Education Journal, 33(3), 145-150. doi: 10.1007/s10643-005-0038-y

4. Belfield C., Bowden A.B., Klapp A., Levin H., Shand R., Zander S. (2015). The economic value of social and emotional learning. Journal of Benefit-Cost Analysis, 6(3), 508-544. doi: 10.1017/bca.2015.55

5. Bolger N., Davis A., Rafaeli E. (2003). Diary methods: Capturing life as it is lived. Annual Review of Psychology, 54(1), 579-616. doi: 10.1146/annurev.psych.54.101601.145030

6. Brackett M.A., Rivers S.E. (2014). Transforming Students' Lives with Social and Emotional Learning. In R. Pekrun, L. Linnenbrink-Garcia (Eds.), Handbook of Emotions in Education. New York: Taylor \& Francis.

7. Bradberry T., Greaves J. (2009). Emotional Intelligence 2.0. San Diego: TalentSmart.

8. Briers S. (2008). Superpowers for Parents. The psychology of great parenting and happy children. London: Pearson Education.

9. Clarke A.M. (2011). An Evaluation of Zippy's Friends, an Emotional Wellbeing Programme for Children in Primary Schools. (Thesis for the Degree of Doctor of Philosophy, National University of Ireland Galway, Galway). Retrieved from https://aran.library.nuigalway.ie/handle/10379/2624

10. Clark D. (2018). A 21-Day Step by Step Guide to Mastering Social Skills, Improve Your Relationships, and Boost Your EQ. Scotts Valley: CreateSpace Publishing.

11. Cowen A.S., Keltner D. (2017). Self-report captures 27 distinct categories of emotion bridged by continuous gradients. PNAS, 114(38). doi: 10.1073/pnas.1702247114 
12. Čiužas R. (2013). Mokytojo kompetencijų nuolatinė kaita [Constant Change in Teacher Competences]. Overview of research papers. Vilnius: Edukologija. Retrieved from https://docplayer.net/50229617-Renaldas-ciuzasmokytojo-kompetenciju-nuolatine-kaita.html (in Lithuanian)

13. Durlak J. A., Domitrovich C.E., Weissberg R.P., Gullotta T. P. (Eds.). (2015). Handbook of social and emotional learning: Research and practice. New York, NY: The Guilford Press.

14. Ekman P. (2007). Emotions Revealed: Recognizing Faces and Feelings to Improve Communication and Emotional Life ( $2^{\text {nd }}$ ed.). New York: Holt Paperbacks.

15. Engin M. (2011). Research diary: A tool for scaffolding. International Journal of Qualitative Methods, 10(3), 296-306. doi:10.1177/160940691101000308

16. Goleman D. (2005). Emotional Intelligence: Why It Can Matter More Than IQ (10 ${ }^{\text {th }}$ ed.). New York: Bantam.

17. Goleman D., Boyatzis R.E., McKee A. (2013). Primal Leadership, With a New Preface by the Authors: Unleashing the Power of Emotional Intelligence. Brighton: Harvard Business Review Press.

18. Hagelskamp C., Brackett M.A., Rivers S.E., Salovey P. (2013). Improving Classroom Quality with the RULER Approach to Social and Emotional Learning: Proximal and Distal Outcomes. American Journal of Community Psychology 51(3-4): 530-43. doi: 10.1007/s10464-013-9570-x

19. Heckman J.J., Kautz T. (2012). Hard evidence on soft skills. Labour Economics, 19(4), 451-464. doi: 10.1016/j.labeco.2012.05.014

20. Heckman J.J., Masterov D.V. (2007). The productivity argument for investing in young children. Review of Agricultural Economics, 29(3), 446-493. Retrieved from http://jenni.uchicago.edu/papers/Heckman_Masterov_RAE_2007_v29_n3.pdf

21. Lazdin R. (2018). Vienas vaikas - 7 intelektai [One child - 7 intelligencies]. Vilnius: Alma littera. (in Lithaunia)

22. Levin H.M. (2012). More than just test scores. Prospects, 42(3), 269-284. doi: 10.1007/s11125-012-9240-Z

23. Mayer J.D., Salovey P. (1997). What Is Emotional Intelligence? In P. Salovey, D.J. Sluyter (Eds.), Emotional Development and Emotional Intelligence: Educational Implications. New York: Basic Books, 3-31. Retrieved from http://ei.yale.edu/wp-content/uploads/2014/02/pub219_Mayer_Salovey_1997.pdf

24. Nathanson L., Rivers S.E., Flynn L.M., Brackett M.A. (2016). Creating emotionally intelligent schools with RULER. Emotion Review, 8(4), 306-310. doi: 10.1177/1754073916650495

25. Navickienė L. (2016). The Parity of Educational Aims: The Potential of Methods of Personal Meaning and Emotional Imitation in Structuring Music Class. In the International Scientific Conference Music Science Today: the permanent and the changeable, 10. Daugavpils: Daugavpils University, 280-295.

26. Navickienè L., Navickas A. (2005). Būsimuju mamu dainos [Songs of Mother-to-Be]. Vilnius: Kronta. (in Lithuania)

27. Navickienė L., Rauduvaitė A., Gabnytė G., Hebert D.G. (2019). Emotional Imitation Method in the context of Lithuanian music education. In D.G. Hebert, T.B. Hauge (Eds.), Advancing music education in Northern Europe. Routledge, 192-221.

28. Piličiauskaitè L., Navickas A., Piličiauskas A. (2017). Šeimos knyga [The Family Book]. Vilnius: Sèkmės vaikai. (in Lithuanian)

29. Plutchik R. (2000). Emotions in the Practice of Psychotherapy: Clinical Implications of Affect Theories. Washington DC: American Psychological Association. doi: 10.1037/10366-000

30. Rosenthal M.K., Gatt L. (2010). Learning to Live Together: training early childhood educators to promote socio-emotional competence of toddlers and pre-schoolchildren. European Early Childhood Education Research Journal, 18(3), 373-390. doi: 10.1080/1350293X.2010.500076

31. Skripkienè R. (Ed.). (2005). Metodinès rekomendacijos ikimokyklinio ugdymo programai rengti [Methodological Recommendations for Development of Early Childhood Education Programme]. Vilnius: Lietuvos Republikos Švietimo ir mokslo ministerija. Retrieved from https://www.smm.lt/uploads/documents/Pedagogams/Visas.pdf (in Lithuanian)

32. Slušnienė G., Balčètienė A. (2016). Emocinio intelekto ugdymas ikimokykliniame amžiuje [Development of Emotional Intelligence in Pre-School Age]. Mokslo taikomieji tyrimai Lietuvos kolegijose, 12, 183-189. Retrieved from http://ojs.kaunokolegija.lt/index.php/mttlk/article/view/127 (in Lithuanian)

33. Tracy B. (2010). Goals! How to Get Everything You Want -- Faster Than You Ever Thought Possible ( $2^{\text {nd }}$ ed.). San Francisco: Berrett-Koehler Publishers.

34. Weissberg R.P., Elias M.J. (1993). Enhancing young people's social competence and health behavior: An important challenge for educators, scientists, policymakers, and funders. Applied and Preventive Psychology, 2(4), 179-190. doi: 10.1016/S0962-1849(05)80088-5

35. Winnicott D.W. (1992). The Child, the Family and the Outside World. (2 $2^{\text {nd }}$ ed.). New York: Perseus Publishing. 